\title{
Factor Analysis Affecting Quality of Life of PLWHA at the Community Health Center
} Service

\author{
Lusiana Hermawaty ${ }^{1}$, Asriwati Amirah ${ }^{2}$, Jitasari $^{3}$
}
${ }^{1}$ Student of Master's Degree in Public Health Sciences, Helvetia Health Institute, Medan, Indonesia
${ }^{2}$ Lecturer at the Faculty of Public Health, Helvetia Institute of Health, Medan,Indonesia
${ }^{3}$ Faculty of Health and Health Pharmacy, Helvetia Institute of Health, Medan,Indonesia Received: May 22, 2021 Received in Revised: June 21, 2021 Accepted: July 4, 2021

\begin{abstract}
Until now, HIV infection is still a global health problem. Handling of HIV infection cases still faces many problems due to various factors. As a result of these factors can also affect the quality of life of PLWHA. The purpose of this study was to analyze the influence of factors from knowledge, attitudes, stigma and family support on the quality of life of PLWHA at the Community health center Service of Teladan in 2020. This study used an analytic survey design with a cross-sectional approach. The sample size in the study was 93 people. The measuring instrument used is a questionnaire. The bivariate analysis used was the Chi-square test and the multivariate with the multivariable logistic regression test. A total of 72 respondents $(77.4 \%)$ were male and 63 respondents $(67.4 \%)$ were adults. From the results of the multivariate analysis, the sig values of knowledge $(p=0.013)$, attitudes $(p=0.045)$, stigma $(p=0.045)$ and family support $(p=0.001)$ were obtained. It was found that there was an influence of knowledge, attitudes, stigma and family support factors on the quality of life of PLWHA. From the results of this study, it is hoped that it can improve services to PLWHA and provide understanding about HIV-AIDS to patients, families and also the community in order to reduce stigma and discrimination against PLWHA.
\end{abstract}

Keywords: HIV Infection, PLWHA, Quality of Life

\section{Introduction}

HIV infection or Human Immunodeficiency Virus is a global health threat until now. HIV infection causes the immune system to weaken because HIV attacks immune cells, especially monocytes and T lymphocytes (Naif, 2013). If HIV infection is not treated, within a few years it will enter the stage of AIDS or Acquired Immunol efficiency Syndrome. At the AIDS stage, people living with HIV-AIDS (PLWHA) are very susceptible to various diseases, especially opportunistic infections (infections that occur when the body's immunity weakens). Opportunistic infections that can attack people living with PLWHA are candidiasis, toxoplasmosis, tuberculosis, cryptococcosis, histoplasmosis and so on (Vaillant \& Naik, 2020).

In 2019, an estimated 38 million people were infected with HIV with 1.7 million new cases in 2019. Around 690,000 people died from AIDS-related diseases. About $81 \%$ of PLWHA know that they have been infected with HIV, from $81 \%$ of PLWHA around $82 \%$ are receiving treatment and $82 \%$ of PLWHA are undergoing treatment, about $88 \%$ of which the virus levels in the blood have been successfully suppressed (UNAIDS, 2020). This is still below the target set by UNAIDS, namely $90 \%$ of PLWHA know their HIV status, 90\% of PLWHA who have been diagnosed with HIV infection must receive treatment and 90\% of PLWHA who have received treatment are expected to have successfully suppressed viral levels in the blood 
(UNAIDS 2020). There are many factors that influence the non-achievement of treatment targets for PLWHA. Factors such as remote access to health services, poverty, knowledge and misperceptions about HIV treatment, lack of social and cultural support are factors that can hinder the achievement of the treatment targets set by UNAIDS (Tomori et al., 2014).

These factors can also affect the quality of life of PLWHA. By improving these factors can help improve the quality of life of PLWHA. For example, 1 in 5 PLWHA will avoid undergoing treatment because they are afraid of being stigmatized and discriminated against regarding their status as PLWHA. When PLWHA avoids treatment, the course of the disease will be more severe and the response to anti-HIV treatment given will be lower. This will reduce the quality of life of PLWHA and increase mortality in PLWHA. A clinic in Namibia when creating a program that focuses on responding to stigma and discrimination and increasing access to services and treatment of PLWHA helps reduce the number of deaths in PLWHA by $20 \%$ (UNAIDS, 2017).

Based on the description that has been explained that many factors affect the quality of life of PLWHA. The purpose of this study was to analyze the factors that affect the quality of life of PLWHA at the Community Health Center of Teladan.

\section{Methods}

\section{Characteristics of Participants and Research Design}

This study uses an analytical survey design with a cross-sectional approach. Participants in this study were HIV patients who were treated at the Community Health Center of Teladan and had been taking medication for 1 year.

\section{Sampling Procedure}

The location of this research was carried out at the Community Health Center of Teladan Medan City and was carried out in February 2021. The sample selection used purposive sampling technique with the sample meeting the criteria required by the researcher.

\section{Sample Size, Sample Strength and Precision}

The sample size in this study used the Taro Yamane formula (Nottidge et al., 2019), which is as follows:

$$
n=\frac{N}{1+N(d)^{2}}
$$

$\mathrm{n}$ is the research sample size

$\mathrm{N}$ is the study population (660 people)

$\mathrm{d}$ is the sample power (derived from a 1-precision calculation)

Precision $(90 \%)$

From the results of the calculation with the formula, it was found that the sample size was 93 people.

\section{Data measurement}

The data used in this study are primary data and secondary data. Primary data in the form of data collected through questionnaires answered by direct respondents. The variables measured in this study consisted of independent variables, namely knowledge, attitudes, stigma and family support, while the dependent variable was quality of life. The questionnaire that was tested for validity and reliability was a questionnaire that involved questions on the variables 
of knowledge, attitudes, stigma and family support, while the questionnaire related to quality of life used the standardized WHOQOL HIV BREF questionnaire.

The knowledge variable is the patient's understanding of HIV disease, there are as many as 20 questions. Knowledge is said to be good if the patient answers correctly as many as 16-20 questions, it is enough if he answers 12-15 questions correctly and less if he answers correctly under 12 questions. The attitude variable is the patient's response to HIV disease and its treatment. There are 20 questions for the attitude variable using a Likert scale with the category being said to be good if the score reaches 51-80 and not good if the score reaches 20-50. The stigma variable is a label attached to a person in society related to the value attached to a person. Consisting of 40 questions using a Likert scale with the category the score results are said to be positive if the total score reaches 101-160 and negative if the total score reaches 40-100.

The variable of family support is the concern of family members towards PLWHA undergoing HIV treatment. Consisting of 22 questions, it is said that family support is good if the respondent's score reaches 12-22 and less if the score is below 12. Quality of life is the achievement of the life of PLWHA with what they want. Consists of 31 questions and is said to have good quality of life if the score reaches 77.5 and less if the score is $<77.5$.

For secondary data used in the form of data collected by the Community Health Center of Teladan through medical records.

\section{Data Analysis}

The data that has been collected is then grouped to see the characteristics of the respondents. To determine the analysis of the effect of the independent variable on the dependent variable using the Chi-square statistical test. In addition, in order to determine the effect of 1 or more independent variables on the dependent variable using Multivariable Logistic Regression

\section{Results and Discussion}

The majority of respondents in this study were adults $(67.7 \%)$ and male $(77.4 \%)$. The characteristics of the respondents are summarized in table 1.

Table 1. Characteristics of respondents

\begin{tabular}{|l|c|c|}
\hline \multicolumn{1}{|c|}{ Ages } & Frequency & $\begin{array}{c}\text { Percentage } \\
(\%)\end{array}$ \\
\hline Teenagers & 19 & 20.4 \\
\hline Adults & 63 & 67.7 \\
\hline Elderly & 11 & 11.8 \\
\hline$\quad$ Gender & 72 & 77.4 \\
\hline Male & 21 & 22.6 \\
\hline Female & 3 & 3.2 \\
\hline \multicolumn{1}{|c|}{ Education } & 64.5 \\
\hline Junior high school & 30 & 32.3 \\
\hline $\begin{array}{l}\text { Senior high } \\
\text { school }\end{array}$ & & \\
\hline Higher education & 30 & 64.5 \\
\hline Marital status & & 35.5 \\
\hline Not yet & 60 & \\
\hline Married & 33 & \\
\hline $\begin{array}{c}\text { Duration of } \\
\text { Diagnosis }\end{array}$ & & \\
\hline
\end{tabular}




\begin{tabular}{|l|c|c|}
\hline$<4$ years & 59 & 63.4 \\
\hline$>4$ years & 34 & 36.6 \\
\hline$\quad$ Risk factor & & \\
\hline Couple & 28 & 30.1 \\
\hline Free sex & 64 & 68.8 \\
\hline syringe & 1 & 1.1 \\
\hline $\begin{array}{c}\text { Treatment } \\
\text { Duration }\end{array}$ & & \\
\hline$<4$ years & 62 & 66.7 \\
\hline$>4$ years & 31 & 33.3 \\
\hline Total & 93 & 100.0 \\
\hline
\end{tabular}

From the measurement results with the questionnaire, as many as 20 respondents $(21.5 \%)$ have good knowledge, 47 respondents $(50.5 \%)$ have sufficient knowledge and 26 respondents $(28 \%)$ have less knowledge. In terms of attitude, as many as 47 respondents $(50.5 \%)$ have a good attitude. In terms of the stigma factor, $49(52.7 \%)$ respondents had a negative stigma. Based on family support, as many as 42 respondents $(45.2 \%)$ lacked family support. In terms of quality of life, 28 respondents (30.1\%) had poor quality of life (table 2).

Table 2. Frequency of variable factors

\begin{tabular}{|c|c|c|}
\hline Variable & Frequency & $\begin{array}{c}\text { Percentage } \\
(\%)\end{array}$ \\
\hline $\begin{array}{l}\text { Knowledge } \\
\bullet \quad \text { Less } \\
\bullet \quad \text { Enough } \\
\bullet \quad \text { Good } \\
\text { Attitude } \\
\bullet \quad \text { Less } \\
\text { good } \\
\bullet \quad \text { Good } \\
\text { Stigma } \\
\bullet \quad \text { Positive } \\
\bullet \quad \text { Negative } \\
\text { Family support } \\
\bullet \quad \text { Less } \\
\bullet \quad \text { Good } \\
\text { Quality of life } \\
\bullet \quad \text { Less } \\
\bullet \quad \text { Good }\end{array}$ & $\begin{array}{l}26 \\
47 \\
20 \\
46 \\
47 \\
44 \\
49\end{array}$ & $\begin{array}{c}28 \\
50,5 \\
21,5 \\
\\
49,5 \\
50,5 \\
\\
47,3 \\
52,7 \\
45,2 \\
54,8 \\
\\
30,1 \\
69,9\end{array}$ \\
\hline
\end{tabular}

Based on the Chi-square analysis that the factors of knowledge, attitudes, stigma and family support have a significant relationship with the quality of life of PLWHA (table 3).

Table 3. Chi-square analysis of independent variables on the dependent variable

\begin{tabular}{|c|c|c|c|c|c|}
\hline \multirow{2}{*}{ Variable } & \multicolumn{3}{|c|}{ Quality of life } & \multirow{2}{*}{ P value } \\
\cline { 2 - 5 } & \multicolumn{2}{|c|}{ Less } & \multicolumn{2}{|c|}{ Good } & \multirow{2}{*}{ f } \\
\cline { 2 - 5 } & \% & f & \% & \\
\hline Knowledge & & & & & \\
• Less & 17 & 18,3 & 9 & 9,7 & \\
- Enough & 8 & 8,6 & 39 & 41,9 & 0,000 \\
\hline
\end{tabular}




\begin{tabular}{|c|c|c|c|c|c|}
\hline $\begin{array}{l}\bullet \quad \text { Good } \\
\text { Attitude }\end{array}$ & 3 & 3,2 & 17 & 18,3 & \\
$\bullet \quad$ Less good & 24 & 25,8 & 22 & 23,7 & 0,000 \\
$\bullet \quad$ Good & 4 & 4,3 & 43 & 46,2 & \\
$\begin{array}{c}\text { Stigma } \\
\bullet \quad \text { Positive }\end{array}$ & 5 & 5,4 & 39 & 41,9 & 0,000 \\
$\begin{array}{c}\bullet \text { Negative } \\
\text { Family support }\end{array}$ & 23 & 24,7 & 26 & 28 & \\
$\bullet \quad$ Less & 24 & 25,8 & 18 & 19,4 & \\
$\bullet \quad$ Good & 4 & 4,3 & 47 & 50,5 & 0,000 \\
\hline
\end{tabular}

Of the factors known to have a significant relationship with quality of life, multivariable logistic regression analysis was performed to determine which independent variable had the most influence on the dependent variable. The results of the multivariate analysis showed that family support had a significant effect on PLWHA (table 4). With family support will provide 10.4 times the possibility of a better quality of life for PLWHA. The greater the support from the family, the better the quality of life of PLWHA.

Table 4. Multivariate analysis of independent variables on the dependent variable

\begin{tabular}{|l|l|l|l|l|l|}
\hline \multirow{2}{*}{ Variable } & \multirow{2}{*}{ B } & P & \multirow{2}{*}{ OR } & \multicolumn{2}{c|}{ 95\% C.I } \\
\cline { 5 - 6 } & & (Sig) & & Lower & Upper \\
\hline Knowledge & 1.215 & 0.013 & 3.371 & 1.297 & 8.761 \\
Attitude & 1.441 & 0.045 & 4.225 & 1.030 & 17.335 \\
Stigma & 1.396 & 0.049 & 4.038 & 1.005 & 16.228 \\
Family support & 2.349 & 0.001 & 10.474 & 2.523 & 43.479 \\
\hline Constant & - & .000 & .000 & \multicolumn{2}{|c|}{} \\
& 8.648 & & & \multicolumn{2}{c}{} \\
\hline
\end{tabular}

From the results of this study, it was found that the factors of knowledge, attitudes, stigma and family support had a relationship with the quality of life of PLWHA. Previous research found that there was a significant relationship to the utilization of CST (Care, Support and Treatment) services. Other research shows that someone who has low knowledge about HIV before being diagnosed with HIV infection has a lower quality of life than someone who already has sufficient knowledge (Kalan et al., 2019). Someone who has good knowledge understands the condition of the disease so that they will be more obedient in undergoing the treatment process. A regular treatment process will also have a good impact on the quality of life.

In terms of attitude, previous research has shown that there is a significant relationship to the behavior of PLWHA on periodic diagnostic examinations (Handayani et al., nd). The attitude of PLWHA's assessment of their health will affect the level of awareness in maintaining health. This lack of attitude can be caused by a lack of knowledge of PLWHA.

Stigma also has an important role in determining the quality of life of PLWHA. This stigma can come from excessive fear of HIV, incomplete information received by PLWHA and the community, resulting in wrong or excessive perceptions and local norms. The stigma received by PLWHA can be in the form of physical stigma (eg separating the use of toilets in the family), social (eg being isolated in the community) and verbal (eg being ridiculed by neighbors) (Dewi et al., 2020). This stigma can affect the emotions and mental health of PLWHA. As a result of this stigma, PLWHA can begin to describe themselves as negative individuals. When they have reached this point of view, generally PLWHA will hide their HIV status, feel isolated and hopeless so that it can hinder the treatment process for PLWHA.One example of evidence of stigma that occurred in Indonesia that had gone viral was the threat of being expelled by three

Copyright @ 2021, Journal of Asian Multicultural Research for Medical and Health Science Study, Under the license CC BY-SA 4.0 
elementary school children from Samosir Regency. This expulsion was carried out by the community because they were worried that their children would be infected with HIV.

Family support is the strongest factor affecting the quality of life of PLWHA in this study (Kusnatalia et al., 2020). In line with the research that family support can improve the quality of life of PLWH (Xiance et al., 2015). In line with research which shows that family support for PLWHA will increase 2.7 times the possibility of a better quality of life for PLWHA (Xu ET AL., 2017). Another study found that with support from the family will increase 3.12 times the possibility for people living with HIV to experience a better quality of life. The existence of family support is important so that PLWHA feel safe, increase self-confidence, minimize stress and discrimination. Family support will also help PLWHA in complying with treatment so that the virus levels in the body decrease, improve clinical PLWHA and improve the quality of life of PLWHA (Desta et al., 2020).

\section{Limitations of the Research}

This study only examines quantitatively the factors that affect the quality of life of PLWHA

\section{Conclusion}

Based on the results of this study, it was found that factors such as knowledge, stigma, attitudes and family support affect the quality of life of PLWHA. Family support is the dominant factor that affects the quality of life of PLWHA in Community health center services of Teladan. In future research, it is hoped that different research variables can be added, namely group support, the role of NGOs and conducting a qualitative assessment of the quality of life of PLWHA.

\section{References}

Desta, A., Biru, T. T., \& Kefale, A. T. (2020). Health related quality of life of people receiving highly active antiretroviral therapy in Southwest Ethiopia. PloS one, 15(8), e0237013.

Dewi, D. M. S. K., Sari, J. D. E., Fatah, M. Z., \& Astutik, E. (2020, February). Stigma and Discrimination Against People Living with HIV and AIDS in Banyuwangi, East Java, Indonesia. In 4th International Symposium on Health Research (ISHR 2019). Atlantis Press (pp. 154-159).

Handayani, T. P., Shaluhiyah, Z., \& Mustofa, S. B. Perilaku ODHA dalam Pemeriksaan Berkala sebagai Upaya Perawatan dan Dukungan (Care and Support) di Kabupaten Pemalang. Jurnal Promosi Kesehatan Indonesia, 10(2), 193-206.

Kalan, M. E., Han, J., Taleb, Z. B., Fennie, K. P., Jafarabadi, M. A., Dastoorpoor, M., ... \& Rimaz, S. (2019). Quality of life and stigma among people living with HIV/AIDS in Iran. Hiv/Aids (Auckland, NZ), 11, 287.

Kusnatalia, K., Fitriani, A. D., \& Amirah, A. (2020). The Effect of Service Quality on Patient's Family Satisfaction in the Nicu Care of the Public Hospital in Datu Beru Takengon Region. Journal La Medihealtico, 1(5), 22-29.

Naif, H. M. (2013). Pathogenesis of HIV infection. Infectious disease reports, 5(S1), 26-30.

Nottidge, T. E., Nottidge, B. A., \& Ekrikpo, U. E. (2019). Prevalence and predictors of low back pain in a Southern Nigerian hospital. Annals of African medicine, 18(3), 167.

Tomori, C., Kennedy, C. E., Brahmbhatt, H., Wagman, J. A., Mbwambo, J. K., Likindikoki, S., \& Kerrigan, D. L. (2014). Barriers and facilitators of retention in HIV care and treatment services in Iringa, Tanzania: the importance of socioeconomic and sociocultural factors. AIDS care, 26(7), 907-913. 
UNAIDS (2017). UNAIDS Warns that HIV-Related Stigma and Discrimination is Preventing People from Accessing HIV Services. Available fom:https://www.unaids.org/en/resources/presscentre/pressreleaseandstatementarchi ve/2017/october/20171002_confronting-discrimination

UNAIDS (2020). Global HIV \& AIDS Statistics. Fact Sheet. 2020. Available from:https://www.unaids.org/en/resources/fact-sheet

Vaillant, A. A. J., \& Naik, R. (2020). HIV-1 associated opportunistic infections. StatPearls [Internet].

Xiance, T. A. N. G., Zhang, Y., Yacong, B. O., Yan, Z. H. A. O., \& Weiquan, L. U. (2015). Quality of life and its related factors in patients with HIV/AIDS in rural China. Iranian journal of public health, 44(3), 412.

Xu, J. F., Ming, Z. Q., Zhang, Y. Q., Wang, P. C., Jing, J., \& Cheng, F. (2017). Family support, discrimination, and quality of life among ART-treated HIV-infected patients: a twoyear study in China. Infectious diseases of poverty, 6(1), 1-10. 